\title{
The Noble Values Contained from Shape and Space of Traditional Malay Residence of Pontianak City
}

\author{
Dada Suhaida ${ }^{1}$, Siswandi $^{2}$ \\ \{civic.link@yahoo.com ${ }^{1}$, rektorat@ikippgriptk.ac.id $\left.{ }^{2}\right\}$ \\ Citizenship Education Study Program, IKIP PGRI Pontianak, Indonesia ${ }^{1}$, History Education Study \\ Program, IKIP PGRI Pontianak, Indonesia ${ }^{2}$
}

\begin{abstract}
The purpose of this study was focused on the meaning and function of the shape and space of traditional Malay residence in Pontianak, and the noble values contained in the noble values contained in the arrangement of traditional Malay residence in Pontianak. Descriptive research method with qualitative research and data analysis techniques; data reduction, data display / presentation, and data verification. Data collection tool; observation, interview quidelines, and study documentation. The results revealed that the meaning of Pontianak traditional Malay residence is very important and has some sacred arrangement of malay traditional residence in Pontianak city came from the values contained in Pancasila, religious beliefs, aesthetic values, social values, and economic values.
\end{abstract}

Keywords: Noble Vaules, Shape and Space Malay Residence

\section{Introduction}

In the life of a cultural society it is a thing that cannot be separated from life together. Culture is the result of activities and inner creation (mind) of humans such as beliefs, arts, and customs, as well as overall human knowledge as social beings used to understand the environment and their experience and guiding behavior. Culture is the identity and characteristics of a nation, culture is something that is very important in shared life that has the noble values contained in it. Culture contains an overall understanding of social values, science and the overall social structure, religion and so on, in addition all intellectual artistic statements that are characteristic of a society [1].

Culture that develops in the community is something that should be expected, especially to show an ethnic and tribal identity in the community. Cultural linkages with society are something that cannot be separated in their environment, because culture and society are a unity in social cultural life. Indonesia has around 500 ethnic groups, each ethnic group has a cultural heritage that has developed over the centuries, which is influenced by Indian, Arabic, Chinese, European, and including its own culture, namely Malay. The Malays live in parts of Malaysia, the eastern coast of Sumatra, around the coast of Kalimantan, Southern Thailand, and small islands that stretch along the Straits of Malacca and the Karimata Strait.

One proof of the existence of Malay tribal culture in Indonesia is in West Kalimantan. The characteristic can be seen from the existence of Traditional Malay Residence located around Kraton Kadariyah Pontianak. The distinctive, unique and beautiful building is always the main attraction for people who see the shape and arrangement of each space. Physical 
buildings always mark the level of development of human life so that each building is loaded with intrinsic value about local wisdom [2]. The form of physical order of dwelling (residential) can be seen as a unified system [3]. Residential houses are a manifestation of social agreement in the sense that the environment is a group of occupations with various facilities. There are 3 (three) aspects that can make benchmarks to see changes in space in a residential house that form a unified system [3], which consists of physical systems, styliatic systems, and spatial systems. Spatial systems (spatial systems) can explain various aspects of benchmarks relating to spatial problems. This system includes the organization of space of hierarchy, space of orientation, and space of relationships. Basically a house can be seen as a system activity mentioned above. Although the 3 (three) aspects above constitute 1 (one) unity of the system but for certain contexts that are related can stand alone.

In Malay culture, the art of building traditional houses is called the Art of Bina. For Malay people, the house has a very important meaning, the house is not only a place to live where daily activities are carried out, but also a symbol of the perfection of life. For most ethnic Malays, it is assumed that a house as a light of life, as a place of descent, as a place for visiting relatives, as a form of parents' responsibility to their children.

Previously relevant research regarding Malay ethnic customs has also been carried out [4]. This research focuses on various forms of ornaments that are widely found in Malay buildings in Medan, and the dominant colors used in Malay building ornaments includes; yellow, green, white, pink, blue, golden, black and brown. Furthermore, the research that is relevant to the research studied by the author is, "Ethnic Occupancy as a Reflection of the Wisdom of Indigenous Peoples on Natural Environment". The search for local wisdom of a culture on two different sites, expected to provide an understanding of how the wisdom of a culture towards its environment, and its purpose can increase appreciation for ethnic culture and architecture [5]. Furthermore, changes in the pattern of traditional Pontianak Malay living space around the Kadriyah Pontianak palace complex in West Kalimantan [3]: (1) a change in the pattern of space that occurred in the house can be considered in the functional plan of the three types of traditional Malay house in Pontianak, (2) in the space organization in all three types of traditional Pontianak Malay residence large (dominant) uses a combined pattern or combination of 2 (two) up to 3 (three) pieces of space organization, namely: Grid, centralized, and linear, (3) in changes in spatial patterns that occur in the hierarchy of space in 3 (three) types of Pontianak traditional Malay residences generally see differences in the livel height of the room floor and the concept of looking at the position of space in a house plan, (4) the orientation of changes in space patterns occurs namely the orientation used; a) facing the natural environment including the path and source of water, the direction of the wind, the direction of the circulation of the sun, b) since the sultanate of Pontianak ruled that there was an additional orientation direction facing the Qibla direction, (5) there were several factors that could change the pattern of space in three (three) types of traditional Pontianak Malay residences, namely; a) internal factors are the addition of family members, development of needs and lifestyle, and value system. External factors are religious factors. Malay traditional houses in Sambas City were also structurally designed to be carried out in fulfilling objectives [6]: 1) safety was obtained from conditions that concern dominance, proportion and balance; 2) value obtained from attention to space construction, space connectedness, structure and pattern structure; 3) fitness is obtained from the selection and pattern of structures; 4) compatibility is obtained from attention to material selection, building orientation and forms of spatial structure; while 5) flexibility is obtained from the arrangement and relevance of space and the selection of structural systems. 
Referring to these findings, it is clear that in the form and arrangement of the Pontianak Traditional Malay Residence also contains local wisdom that is full of noble values which are very important to be observed and preserved by the younger generation today, especially the young generation of Malays who must continue to show the traditions, customs, and habits of the Malays but can still be used as a guide in the joint life. In addition, the noble values contained in customs, especially in traditional Malay residence in Pontianak City can be an alternative learning model for Citizenship Education in recognizing and preserving national culture so that traditional relics are not lost eroded by the times.

Citizenship Education is an educational program that has a core of expanded political democracy with other sources of knowledge, positive influences from school education, society and parents, all of which are processed to train students think critically, analytically, behave and act democratically in preparing for a democratic life based on Pancasila and the 1945 Constitution [7]. Citizenship Education is an effort to equip students with basic knowledge and abilities in relation to citizen relations with the state and preliminary education to defend the country so that citizens can be relied on by the nation and state [7].

From the definition above, it can be assumed that Citizenship Education (PKn) is a lesson that not only focuses on the positive aspects, Civics also have a target in developing active thinking skills for citizens as the younger generation in implementing noble values that are able to exercise rights and its obligations in accordance with the values of Pancasila and the 1945 Constitution, in order to become a young generation that can be relied upon by the nation and state. Of course in this case the young generation of Malays in Pontianak City has became a society that loved customs and culture, and continued to preserve the noble values contained in the form and arrangement of space for Traditional Malay Houses of Pontianak City. The researcher believes that, Malay ethnic customs and culture in particular the existence and preservation of Traditional Malay Residence of Pontianak City are not known and preserved by the Malay young generation undoubtedly the existence of Traditional Malay Residence will gradually diminish and disappear from Kalimantan.

Therefore the author sees it is very interested in studying further to obtain information about the Noble Values contained in the Traditional Malay Residence of Pontianak in City of Pontianak, especially the traditional Malay residences, Cut Limas. Considering that the population of traditional Malay residences in Pontianak has increasingly disappeared and its existence has diminished. Therefore this research was carried out with the aim of obtaining an overview and information about the "noble values contained from the shape and space of Traditional Malay Residence of Pontianak City so that Pontianak Malay people and Pontianak Malay young generations love and preserve customs and Malay culture.

\section{Method}

This study uses a descriptive method with a qualitative approach. The reason for the method and research approach was chosen, because the studied problem was the problem that developing in the community. Through the descriptive method, it is expected that the descriptive phenomenon in the field can be interpreted with deeper meaning and content. Descriptive research method is a research method that is widely used in research that aims to explain an event [8]. Descriptive research is a study that aims to provide or describe a situation or phenomenon that occurs at this time by using scientific procedures to answer the problem actually. 
The approach in this research is qualitative or naturalistic, qualitative research departs from the constructivism philosophy which assumes that the reality is plural, interactive and an exchange of social experiences that are interpreted by individuals. Qualitative research is shown to understand social phenomena from the perspective of participants. Participants are people who are invited to interview, observed, asked to provide data, opinions, thoughts, perceptions [9]. Besides emphasizing the factor of researchers as the main research tool, even this research also considers the method used so that the results are as expected.

This study took place in the vicinity of the Pontianak Krion Kadriyah settlement, with the following considerations; (1) data sources that are directly related to the researchers' problems being investigated around Pontianak traditional Malay residence, (2) historical actors in Pontianak traditional Malay residence are believed to exist, (3) research subjects or informants who have knowledge and abilities regarding Pontianak traditional Malay residences, and (4) researchers are easy to visit research sites. In qualitative research the concept of population and sample is referred to as the subject of research or unit of analysis [10]. The subject of this study relates to what or who was studied. The sample in qualitative research is not called the respondent, but the resource person, or participant, informant, friend, teacher or consultant in the study [10]. Determination of the data source of the people interviewed was done purposively, which was chosen based on certain considerations, because the researcher considered that the informant could trust more to become a data source. Based on this, the subjects in this study were historians who knew about "the shape and space of traditional Malay residences in Pontianak City", then from community leaders, and architectural experts who knew about "the shape and space of traditional Malay City residences Pontianak ".

Data collection techniques in this study were observations, interviews, documentation, and literature studies or literature studies. The data collection techniques will be described as follows: 1) Observation; in everyday life everyone can not be separated from making observations. The meaning of observation in qualitative research, observations made in research go directly to the field to observe behavior and activities and individuals at the research location [11]. Observation in this study by going directly to the field and observing how the teaching and learning process creates a conducive atmosphere. It is expected that by observing researchers can obtain valid data, so that the results obtained are truly in accordance with the reality that occurs in the field; 2) Interviews, with interview techniques, the main data in the form of speech, thoughts of feelings and actions of the subject, and interview techniques carried out in a planned or structured manner. The implementation of the interview only uses general guidelines or interview guides so that the questions are not fixed on a specific list of questions. In conducting interviews, it will only be done purposively. The interview is the right tool to find out the facts about views, understanding, what is thought or felt, policies, related to the contained noble values of the form and space of traditional Malay residences in Pontianak City; 3) Documentary study, Documentation study is one of the qualitative research data sources that has long been used, because it is very useful. Qualitative data collection through documents can be made public documents (newspapers, magazines, reports), or privacy documents (diaries, letters, e-mail) and audio-visual material in the form of photographs, objects -jobs, art, vidio tape [11]. Images or monumental works from someone; 4) One-to-one Study Literature study, namely a data collection tool to reveal various relevant theories by questioning what is being faced or examined as material for discussion of research results [8].

The data analysis technique used in this study consists of three lines of activities that occur in an equation, namely, data reduction, data presentation, conclusion drawing or verification [12]. Furthermore, qualitative data analysis is an effort that continues, repeats and 
continuously. The problem of data reduction, data presentation (data display), drawing conclusions (conclusions) is a series of analysis activities that follow each other.

\section{Research and Discussion}

\subsection{The Meaning and Function of the Spatial Arrangement at the Traditional Malay Residence of Pontianak}

House is everyone's dream and of course a house has a meaning of establishment for the houseowner. For Malays, residential houses is a gathering place for all family members and a place to share experiences and a place to share love among family members. Traditional Malay residence Pontianak City is a building that has a function as a place to live. The house is a place for all family members to stay in activities that become a daily routine. For Malay people, the house can be a source of peace, inspiration, and positive energy for the owner who lives in the house.

The findings of researchers in the field revealed that the meaning and function of Traditional Houses of Pontianak City meant to symbolize the welfare of its inhabitants, the meaning of Malays living in Pontianak City was not just a place to live, but for Pontianak Malays the house symbolized the perfection of life. Some expressions about traditional Pontianak Malay residences devastate traditional residences as; (1) the place of stay of relatives, (2) the place of religious descent, and (3) is the light of life on earth. According to information in the field of the meaning of houses for Pontianak Malays the house of residence also means as a form of responsibility for his family or not, and for Malays who are not housemakers themselves are usually considered to be less common. Therefore Pontianak Malays always try to establish their homes despite the very simple form of a house.

Pontianak Malays also crave a good and perfect residence, whose physical buildings fulfill the customary requirements and the needs of its inhabitants. While in terms of spiritual meaning according to Pontianak Malays, a well-built residence can bring happiness, peace and comfort to its inhabitants. This made the Pontianak Malay house to be built with good considerations, by not ignoring symbols or symbols which were a reflection of the cultural values of the Pontianak Malays. By following this method, it is hoped that a living of Pontianak Malays can provide good fortune for the residents.

According to the tradition of Malays, Malays believe that in building a house should be established through the procedures for making according to customary provisions, using an orderly procedure then a building can be said to be a real home. In building a traditional Malay house, Islamic law is very concerned. Usually the location of men's space is different from the space of women, carvings are rarely made with animal or human motifs. Looking at the expressions of traditional Malay houses for Pontianak people, it can be said that the expression is a growing local wisdom culture, it can be said that the expression is a culture of local wisdom that develops in Pontianak Malay society, whose culture comes from the word Buddayah as the plural from Buddhi (Sanskrit) which means "reason" culture is the whole of human activities, including knowledge, beliefs, art, morals, law, customs and other habits [13],[14].

It can be concluded while that, the meaning of Pontianak's traditional Malay residences is very sacred, because for Pontianak Malays traditional houses must be built with careful consideration, without disregarding the values contained therein so that it is a reflection of 
Pontianak Malay culture values . In this way, a traditional Pontianak Malay residence is believed to be able to provide birth and mental well-being for residents of the house and surrounding communities.

Next is the function of the traditional Malay house in Pontianak, the type of Limas Cut. Pontianak traditional Malay residences of pyramid type have long rectangular plan located parallel to or extending perpendicular to the road / river in the form of pyramid roofs consisting of 2 (two) isosceles triangles and 2 (two) fields trapezium which is joined by 2 (two) sides in the form of a rectangular field. Based on the findings in the Pontianak traditional Malay residential field, this pyramid type cut is larger and wider in terms of floor plan and has special construction techniques in the construction process, and this pyramid-type housing has grandeur.

In traditional Pontianak Malay residences, the Potong Limas type tends to be established and is owned by Pontianak sub-Malays who have social status and middle to upper wealth. For these plans, the house plans for the pyramid-type housing are more likely to be square or rectangular and are a stilt house which has the basic building material predominantly made from wood. Typology of Pontianak's traditional Malay house is a house on stilts or clans, and has high pillars. This is in accordance with the local climate and habits that have been passed down for generations. The house support pole is about two to two and a half meters tall. The height of the upper main house is about three or three and a half meters. The atmosphere in the room is cool and fast because many have windows and vents.

Every room in a traditional Malay residence has a certain name and function. In the traditional Malay house of Pontianak, the Potong Limas type has 3 (three) collections of core parts of the building (houses) arranged horizontally and vertically, namely: (1) part of the main house / core (mother's house) covering the terrace room (Pavilion), living room (front / front porch), Bedroom (cubicle), living room (middle room / central porch / ambin), and parquet room (para / attic; (2) children's home part (kitchen house) / support) includes the kitchen room (pedapuran / sayuk) as a supporting part of the house, and (3) the intermediary part includes the equipment / delivery room (hoses), the main house / core (mother's house) and the children's house (kitchen / supporting house) connected with the intermediate part (liaison), namely the delivery room (delivery / hose).

The function of the traditional Pontianak Malay residence is seen in the main house / core (mother's house) covering the terrace room (pavilion / porch), living room (front porch / front), bedroom (cubicle), family room (room middle / central foyer / ambin), and parak room (para / loteng, which is functioning as a traditional residential house physically functioning as a place to live and a place to run the activities of a family of one folk, is a main and important house among other houses in one folk. Besides as a residential place, it also functions as a place of consensus and a place to carry out traditional ceremonies, which causes the space in the traditional Pontianak Malay residences to consist of private spaces and spaces used to gather together to discuss problems. Therefore traditional Malay Pontianak residence is a house that is inhabited according to customary rules and norms, so that life in a traditional residential house is called a small, and large chamber. For the direction of the function of the space in the main house as an area where the family meets and the residents of the traditional Malay residences often regard the space as a multifunctional space that can be used for various activities or certain activities in a residential house. For example: for an additional living room, prayeing room, lectures, wedding activities. In addition, the main room / core functions as a place to put guests' things. The front porch room serves as a place to receive male guests, close neighbors, honorable and elder people. The central foyer room or main room also functions as a place to receive great guests who are highly respected. The side hose room from 
the main house / core serves as a place to put items that are not carried into the back porch room. Besides this side hose room is the entrance for female guests.

The function of Pontianak's traditional Malay house space is; the house part of the child (kitchen / supporting house) includes the kitchen room (pedapuran / sayuk) as a supporting part of the house, which serves as a place for activities for cooking, storing items for the kitchen. And the kitchen / support room usually has a rare arrangement of floor boards, so that trash can be directly thrown to the ground. For space under the house is usually used as a place to work everyday and store home appliances. While the equipment / delivery room functions as a connecting place from another room. In addition, the courtroom usually functions as a place to wash dishes, use. While the toilet (latrine) and sometimes livestock (chicken or goat) are usually located slightly behind the house.

However, in the traditional Malay house of Pontianak, this type of Limas cut will continue to undergo a process of development and change, where at that time there is an adaptation process or adaptation to the development of human needs, economic, cultural and environmental factors especially in complex environments. Pontianak Kraton Kadriyah. Adjustments to these developments can also occur together with the development of Pontianak Malay culture and traditions in West Kalimantan (especially in Pontianak) [3]. Furthermore according to the findings in the field, that the layout of the traditional Malay house in Pontianak, the type of piece of Limas, has now undergone many developments and changes from the initial plan (space and initial functions). The rules of tradition and customs that have been adopted and applied from generation to generation in the present in Pontianak's traditional Malay house, for example: the tradition of circumcisions, hair clippers / aqiqahan, and others. From some of the traditions and customs mentioned above there are traditions and customs that are no longer adhered to or that are not strictly enforced again by the Pontianak sub-Malays who live around the Pontianak Kratin Kadriyah Complex, especially those who live in the house today or now. In fact they actually do not close themselves to outside influences about the changes and developments of the times, as long as they do not conflict with their culture. These changes are illustrated by research conducted by [3], about changes in organizational patterns, hierarchy and orientation of the traditional Malay house living room of Pontianak type of Limas Cut Around the Kraton Complex of Kadriyah Pontianak, traditional Malay residence Pontianak is a residence for one family which is the smallest social unit [3]. Pontianak's traditional Malay residences are generally influenced by Islamic teachings, Pontianak Malay customs, and Pontianak Kadriyah Kraton that still survive today. To classify the types (types) of traditional Pontianak Malay residences based on the highest levels of hierarchy, which are divided into pyramid cut types, Godang cut types, and wire cut types. Phenomenon that occurred in Pontianak sub-community who lived in the vicinity of Pontianak's Kadriyah Kraton Complex, which is still the presence of some people who still adhere to Pontianak's Malay customs and traditions as well as those from Pontianak's Kraton Kadriyah. However, on the other hand, there are also a number of Pontianak sub-Malays who have experienced a development and shift in paradigm of thought (changing patterns of thinking). This development has an effect on the culture of Pontianak sub-Malays which is related to the activity, physical, and pattern of living space at this time. Therefore there are parts that are still maintained and there are also parts that experience changes. There was a change in the pattern of the traditional Malay-type residential house Pontianak Potong Limas Type, covering various things, namely: space organization, space hierarchy, and space orientation.

The findings of this study are reinforced on the value and meaning of the local wisdom of Palembang traditional Limas house as a criterion of Malay people, who concluded that: 1) 
Palembang traditional houses have local wisdom that has value and mean; 2) the local wisdom is manifested in many physical forms (functional form of building, ornament, and construction) or intangible (meaning and value of philosophy, religious values, traditions, arts, moral values, and knowledge) but the benefits can be felt; 3) the local wisdom of the Palembang Traditional House is related to the traditions and culture of the Malay people, it can be seen that the meaning and value contained in local wisdom is in accordance with the criteria of the Malay community; 5) It can be concluded that the Palembang community is part of the Malay community [15].

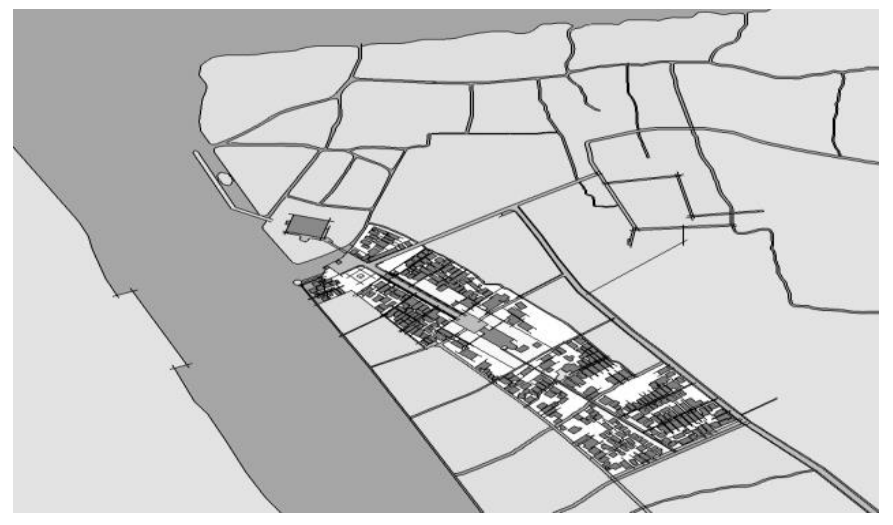

Fig. 1. Location of Existence of Traditional Malay Pontianak Residence Potong Limas Type Around the Kraton Kadriyah Complex (Pontianak Sultanate)(Source: Adapted and redrawn from IKONOS Satellite Imagery Pontianak City coverage in 2010 and Google Earth: 2011 Field Survey Document: Usmardan, 1998 in Ciptadi, W. 2014)

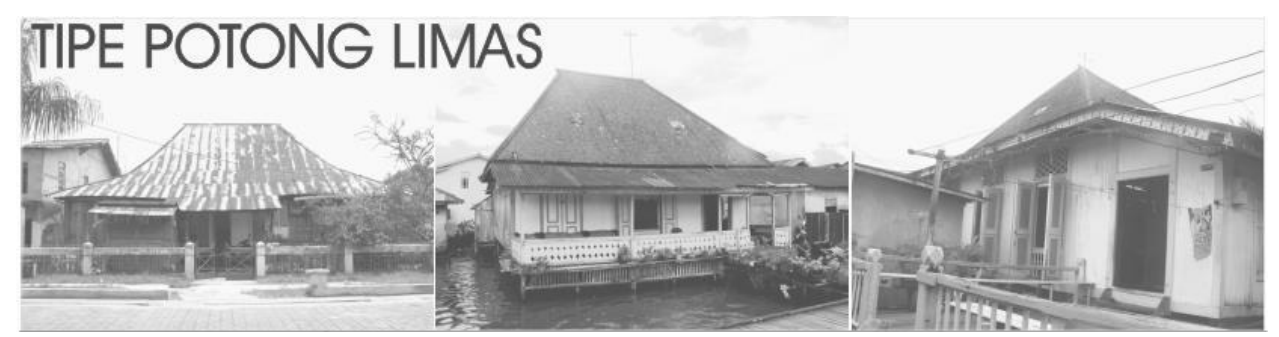

Fig. 2. Traditional Malay Pontianak Residence Potong Limas Type.(Source: Adapted and redrawn from IKONOS Satellite Imagery Pontianak City coverage in 2010 and Google Earth: 2011 Field Survey Document: Usmardan, 1998 in Ciptadi, W. 2014)

Although traditional Malay residences in the city of Pontianak on the Potong Limas Type have undergone many changes in the pattern of space orientation, however, the function and form of the residence as dwellings and places to carry out joint activities in the family. 


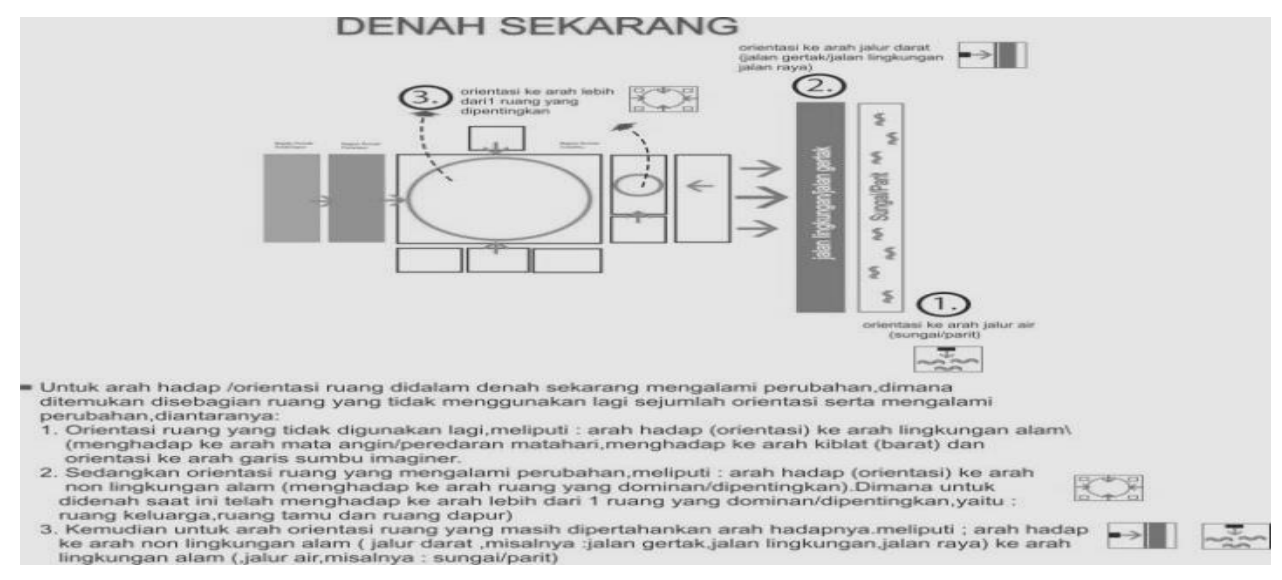

Fig. 2. Changes in the Pattern of Space Orientation in the Current Plan Traditional Malay Residence on Pontianak City Potong Limas Type (Source: Ciptadi, W. (2014)

From the above explanation it can be concluded that, the function of the form of Pontianak's traditional Malay residential houses in pyramid-type type has undergone several changes which include: (1) the orientation of space that is no longer used covers the direction towards the natural environment (facing the sun / sun nursery, facing towards the Qibla and towards the imaginary axis line; (2) the space undergoing change includes: the direction towards the non-natural environment (facing towards the dominant space currently facing toward more than 1 dominant / important space, namely: family room, living room and kitchen room; (3) the space that is maintained in its direction includes: the direction of the natural environment (waterway, for example, river / ditch) and space, but the meaning and function of the arrangement of space from Pontianak's traditional Malay residences still adhere to Malay culture and ethnicity namely; as a place to live and place to carry out joint activities in the family. As for the size of a traditional Pontianak Malay residence built on the economic capacity of the homeowner, for traditional Pontianak Malay residences with the Limas cut type, usually only Malays have a good economy, because traditional houses of this type are larger and more magnificent than residential houses other traditional Pontianak Malays. Aside from being a place of residence, this traditional residence is also used as a place of consensus, a place to carry out traditional ceremonies, therefore the space in a traditional residence is divided into private activities in the form of open and wide spaces for joint activities, as private rooms sleeping room, then the activity room for cooking and storing kitchen utensils in the form of a kitchen room (dapok), and a delivery room which is usually used for toilet washing activities.

\subsection{The noble values contained in the function of shape, spatial arrangement in the traditional Malay residence of Pontianak}

In this section we will discuss the noble values contained in the shape, arrangement of space in the traditional Malay house of Pontianak. To find out the cultural values in traditional Pontianak Malay residences it is necessary to discuss the normative aspects expressed through the life view of Pontianak Malay society. The view of Pontianak Malays is used as a guide in personal life, family and society. 
But with the rapid development of science and technology causing the world to feel smaller, besides that it brings various changes in the order of human life. These developments led to a shift and change in cultural values ranging from urban to rural areas. Traditional life is increasingly becoming a taboo and abandonment, each person is busy in racing to put himself in the forefront of competition to seize opportunities for increased welfare. In the rush of competition this tends to occur things that are not fair. Material advancement often causes people to be careless to guard and maintain a balance between the outward and the inner side. Science and technology are not infrequently broken down which will trap people in the context of changes in mindset and behavior that harass the noble values of religion, culture and social norms in their society. It is probable that they will lose those noble values which will ultimately cause a loss of personality and identity. The loss of personality and identity by Malay parents is called "forgetting oneself" or Forgot Pakean "[16].

Furthermore, to find out the noble values contained in the form function, the arrangement of Pontianak's traditional Malay house space requires discussion of normative aspects which are expressed through the life view of Pontianak Malay society as a guide in personal life, family and society. For Malays, science and technology are not a taboo, but instead they must be studied, absorbed and utilized as well as possible. The attitude that is established is to demand and take the knowledge of "heretical" which can bring evil, or take knowledge that is not appropriate and in harmony with the teachings of Islam, and the noble values of its customs. Therefore, the Malay parents asserted, whatever form and type of knowledge adopted must be filtered / filtered first with the size of Islamic faith and harmonized with the noble values of culture and social norms adopted by the community. In the normative view, that the minimum measure of knowledge taken is science that does not bring harm to life in the world and life in the hereafter. The advice of the Malay elders is then seen / manifested in the values adopted. The legal norms that are practiced and the rules implemented are guidelines for living alone, family and society.

Based on the analysis that the noble values contained in the functions of traditional Malay residences in the main / core space are worth that, the main room / core functions as a place to live and protect from hot and rainy weather, while also functioning as a place of activity to receive guests men, close neighbors, respectable people, and elder people, besides that the main house is usually used as a place for deliberations, places of descent, such as conducting aqiqahan activities, circumcision, the Khatamam Qur'an and so on. The point is the main house / core is more conducive to the value of togetherness and family. It is pointed out that the noble values contained in the main room / core in traditional Malay residences are very important. This indicates that for Malays Traditional residences have very noble values related to the psyche, for them traditional houses that are large and comfortable can provide a sense of security, besides that in terms of the status of the house also gives a sense of pride for its residents.

Furthermore, the sublime values contained in the kitchen (dapok) section, namely, under Pontianak Malays, make the kitchen a place to do daily cooking for family needs, in case there are any events like Aqiqah, or circumcision, kitchen room can be used as a place to do every activity that immediate to prepare every needs, therefore usually the kitchen can be very large in size because usually when there is a kitchen event can be used by more than one person to make preparations immediately. In addition the kitchen is also used as a place to store all cooking programs, namely, cauldron, pan, needs dishes which are usually large in size. Instead of these functions the noble value contained in the function of the kitchen space in traditional Malay houses is, the noble value of mutual cooperation when carrying out the Aqiqah event, circumcision, and other events, which usually cook in the kitchen is not done by one person, 
usually forcing activities for large events will be assisted by several families and close neighbors. Therefore it is not surprising that the traditional Malay type of Limas house is usually large in size.

While the courtroom which functions as a place to carry out washing, bathing, and drying shows that the noble value of the function of the courtyard space is to the noble value of neatness which is very much considered by Malay people who live in traditional residential.

The noble values illustrated above are closely related to the values contained in the values that develop in society, namely values, namely the values expressed by Alport, there are six values contained in people's lives, 6 (six) kinds of values namely: theoretical values, economic values, aesthetic values, social values, political values and religious values. The value of the developing theory in Pontianak Malay society is that in building a house must pay attention to procedures that are in accordance with the advice of old people, such as residential buildings must pay attention to the place where the house faces the Qibla, building a house should be near water. Economic values are also considered, in this case Pontianak Malays also pay close attention to their economic capacity in establishing houses, as traditional houses are built on three types, namely the type of wire which is usually economically adapted to middle and lower, the type of cut which people can usually build Malays who have a middle to upper economy, and the type of Limas cut which is usually only able to be built by Malays who have a high economy, considering the type of Limas slaughterhouse requires materials that are quite expensive so that traditional Limas type houses look more grand and luxurious, and large compared to other types of traditional residential houses.

Afterwards the ethical and social values can also be seen from the beauty of the form of traditional Malay residences, even before setting up houses, the Malays usually still involving relatives and the closest people to deliberate in determining the shape and materials that will be used to build houses. In addition religious values or religious values are also highly emphasized by the Malays, namely that the beliefs of the past in building buildings both houses and palaces, the location of sacred buildings must be near water, the role of water is technically also needed in the construction and maintenance and survival of buildings itself. In order to maintain the sanctity of a place, the area around the center of the building as well as the availability of hotspots is really considered. As the discussion above Notonegoro also mentions there are 3 (three) kinds of values, namely [17]:

1. Material value, which is everything that is useful for human physical life or human physical needs.

2. Vital values, namely everything that is useful for humans to be able to hold activities

3. The value of spirituality, which is everything that is useful for the spiritual person, includes: a) The truth value that comes from reason (ratio, mind, human), b) The value of beauty or aesthetic value that comes from human emotion c) The value of goodness or moral value that comes from the element of human will.

And from some description of the value, that religious value is the highest and absolute spiritual value and comes from one's beliefs or beliefs. Whereas if we refer to the description of the meaning of the basic values of the Pancasila above, namely:

1. Godliness: the divine value of the Almighty contains meaning, that there is a recognition and belief of the nation towards the existence of God as the dreamer of the universe. With this divine value, the Indonesian nation is a religious nation that is not an atheist nation. Furthermore, the value of divinity also means that there is recognition of the freedom to embrace religion, respect for religion, then there is no coercion and not discriminatory between religious communities. 
2. Human values: fair and proper behaviours human values implies awareness of one's attitudes and behaviors in accordance with moral values in a shared life on the basis of the demands of conscience by treating things as they should.

3. The value of unity: implies effort towards unity in the unity of the people to foster a sense of nationalism in the United State of the Republic of Indonesia (NKRI) and to fully acknowledge and respect the diversity possessed by the Indonesian people.

4. Population value: contains the meaning of a government from the people, by the people, and returns to the people by means of deliberation and consensus through its representative institutions.

5. Value of justice; contains meaning as a basis as well as a goal, namely the achievement of a Just and Prosperous Indonesian society outwardly or inwardly.

Thus it can be concluded that, Pancasila as a source of value in Citizenship Education which is used as a source of value in community life, nation and state is Pancasila. This means that the entire order of life of the people, nation and state uses Pancasila as a moral basis or norms and benchmarks of both the bad and the right of the wrong attitude, actions and behavior of the Indonesian people. This is reinforced by the research conducted about the contrusive stages of traditional Malay ethnic houses in Sambas Regency, West Kalimantan, which concluded that Malay ethnic communities in Sambas Regency were very concerned about the stability of traditional Malay residence structures by taking into account the following: a ) Building with high stability in traditional Malay residence in Sambas Regency can be created with a good construction system and refers to normative rules of construction which are naturally understood from generation to generation by traditional Malay communities in Sambas Regency; b) The stages of this construction guarantee the stability of the structure so that each structural element is able to support each other in the Sambas Traditional Malay residence; c) the determination of the system structure and the appropriate construction stages in the Malay Traditional residence in Sambas Regency is able to provide a balance of buildings both transversely and extending the building so that it becomes a stable structure and facilitates the overall stages of construction [18]. The research was conducted by Anisah \& Halimah, L. (2018) about the internalization of the value of citizenship education in the Blanakan rapid sea tradition in the context of developing the Ideal Democratic Citizen. The ceremonial activities of Blanakan sea party traditional ceremonies were not just a party in general, but had sacred cultural values from their ancestors [19]. For this purpose, the fishing community gave rise to civic knowledge about nationality and citizenship which of course could be directed by community leaders. The values contained in the Blanakan sea party that are related to civic skills, in the event of a sea party from the beginning to the end of the activity, always require skillful skills in organizing the organization of sea parties that have relevance between partipatory skills and no intellectual skills. only requires pengtehauan but skills are needed. Forming the character of the Blanakan village fishing community by fostering mutual cooperation in organizing the sea party, this character is reflected in the fishing community. This is in accordance with the values of Citizenship Education which is the basis for the development of The Ideal Democtaris Citizen which contains social values, mutual cooperation, togetherness, not individualism, there is always a collaboration between fishermen. This is contained in the principle of civic disposition, forming the character and character of the Indonesian people. The traditional wisdom of the Sundanese community in relation to the natural environment [20]. Basically, Kanekes Sundanese community wisdom was extracted from the experience of the old Sundanese people who were very familiar with their environment and had long lived in the culture of the farming community. Customary wisdom, a social and cultural condition in it contains a repertoire of cultural values that 
respect and adapt to the environment, and are arranged in a very orderly manner the customs of a society. Although often considered old-fashioned, the values they teach and the practices they carry out are still the best ways to care for the environment in the post-modern era. Furthermore, study of the character based on the values of local wisdom in the indigenous community of Kampung Kuta, Tambaksari, Ciamis Regency concluded that; (1) Indigenous people perceive that local knowledge is a cultural inheritance as a noble value, inherited from ancestors as the formation of identity and identity must be maintained and preserved. The inherited character is soft, orderly, disciplined, sharing concern, teaching each other, sincere, obedient / obedient, visionary (forward thinking), responsible, dedicated, loyal, sympathetic, empathetic, compassion, tolerant, willing to sacrifice, faith and piety, modesty, respect for health, thought, and constructive thinking, reflected in art, proverbs, and ways of life; (2) inheritance of character values carried out by oral traditions and examples transmitted directly through traditional ceremonies; (3) The persistence factor that strengthens the values of local wisdom, is the fact that "pamali" (meaning prohobition), is still held firmly by the community [21]. The Adar Pulo village community is a traditional village until now still exists to hold firmly to the traditions that its ancestors have inherited [22]. This is because they still have customary rules which if violated will get customary sanctions, sanctions for customary law are believed to be sacred. The form of character possessed as a process of internalization of values and can be promoted as the basis for forming the character of the Indonesian nation are, Religious character, Honesty, Tolerance, Discipline, Hard Work, Independent, Democracy, Friendly / communicative, Peaceful love, Environmental care, Social care, and Responsible.Based on the description of previous research and the author's findings on the various values contained, it is clear that the customs of the Malays in this case concerning the noble value of the form and function of Traditional Malay Residence of Pontianak City which buildings are around Pontianak Kraton Kadriyah complex contained the noble values of Pancasila. One of them is religious values, aesthetic values, social values, and economic values. Based on the findings of these values, it can be the basis for the development of learning Citizenship Education in building the character of the young generation to care for the environment and society in loving and protecting the existence and preservation of traditional Malay houses in Pontianak.

\section{Conclusion}

The meaning of Pontianak's traditional Malay residence is very important and sacred to the Malay people, because for the ethnic of Malays Pontianak traditional residence must be built with careful consideration, such as the use of materials and wood, the location of the building site, and the position of the house which usually faces water, with does not exclude the values contained in it so that it is a form of reflection of the cultural values of the Pontianak Malay community. By paying attention to the procedure, it is expected that the Pontianak's traditional Malay residences are believed to provide physical and spiritual well-being for the residents of the house and the surrounding community. In addition, the arrangement of space in Pontianak's traditional Malay residences also has a function of the shape of Pontianak Malaytype residential houses which are: a place to live with family, a place to protect from heat and rain, and as a place for family activities / events. such as: carrying out the Aqiqahan event, the circumcision event, and carrying out private activities in the form of a room as a place to rest. The room in the main house / core also serves as a place to carry out the thanksgiving event to 
thank God Almighty. In addition, the arrangement of the kitchen space serves as a place for activities to cook and store kitchen furniture, and backyard serves as a place for washing, bathing and drying. This traditional type of Limas residential house was built based on the economic capacity of the homeowner, for this type of Potong Limas house it can only be built by Malays who have the economy upwards, because this type looks bigger and more magnificent than the type of Potong Kawat and Potong Godang.

Whereas the noble value of the shape and function of the arrangement of the Pontianak traditional Malay residence which buildings are located in the vicinity of the Kraton Kadriyah Pontianak Complex contains many noble values contained in Pancasila. They are: religious values, aesthetic values, social values, and economic values. It is hoped that the findings of this study can be the basis for developing Citizenship Education learning resources in building the character of the young generation to always care for the environment and the people, protect the existence of Pontianak traditional Malay residences, and preserve customs and cultures that developed in Pontianak Malay community.

Acknowledgments. This research was funded by IKPI PGRI Pontianak with a contract number : 020 / L.202.103 / PPK / III / 2017, therefore the researchers expressed their deepest gratitude to IKIP PGRI Pontianak. In addition, the researchers also thanked lecturer friends at the Pontianak Polytechnic, especially Wahyudi Ciptadi, who provided writers with much supports, directions and informations so that this research could be carried out.

\section{References}

[1] Gumilar, S. \& Sulasman. (2013). Teori-teori kebudayaan dari teori hingga aplikasi. Penerbit Pustaka Setia. Bandung.

[2] Ahimsa-Putra, H.S. (2008). Cultural Scientists and Revitalization of Local Wisdom: Theoretical and Methodological Challenges. Presented at the Open Senate Meeting 62nd Anniversary of the Faculty of Cultural Sciences UGM Yogyakarta March 3, 2008.

[3] Ciptadi., W. (2014). Changes to the Pattern of a Traditional Malay House of Residence in Pontianak Around the Kraton Kadriyah Pontianak Complex, Pontianak, West Kalimantan. Thesis of the Post-Graduate Program Architecture Engineering Study Program at Gadjah Mada University Yogyakarta. (2014)

[4] Kartini. A. (2014). Analysis of the Application of Malay Nuance Ornaments in Terms of Shape and Color in Medan City. Unpublished thesis.

[5] Nurqomariah. S. (2010). Ethnic Occupancy as a Reflection of the Wisdom of Indigenous Peoples' Culture on the Natural Environment. Thesis of the Faculty of Engineering, Department of Architecture, Depok.

[6] Zairin, Z \& Fajar, W. I. (2014). 'Stages of Construction of Traditional Makay Houses in the City of Sambas West Kalimantan'. Vol. 1, No. 2. ISSN 2355-2484 (Print) - ISSN 2550-11994 (Online). http://jurnal.untan.ac.id/index.php/lb/article/view/18805

[7] Somantri, M. N. (2001). Initiating the Renewal of Social Studies Rducation. Rema Rosda Karya. Bandung.

[8] Sugiyono, (2011). Qualitativive Quantitative Research Methods and R\&D. Alfabeta. Bandung.

[9] Sukmadinata, (2006). Educational Research Methods. Remaja Rosdakarya. Bandung.

[10] Komariah, A. \& Djam'an, S. (2010). Quaalitative Research Methodology. Alfabeta. Bandung

[11] Cresswell, J. W. (2010). Research Design: Reseacrch Design: Qualitative Quantitative, and Mixed Approaches. PT Pustaka Pelajar. Yogyakarta.

[12] Miles, M. B. \& Hubermen. A. M. (2007). Qualitative Data Analysis. Resource Book About New Methods. Universitas Indoensia Press. Jakarta

[13] Koentjaraningrat, (1974). Introduction to Antropology. Aksara Baru. Jakarta 
[14] Ratna, N. K. (2005). Literature and Culture Studies: Representation of Fiction and Facts. Pustaka Pelajar. Yogyakarta

[15] Tondi, L. M \& Iryani, Y. S. (2018). 'Value and Meaning of Local Wisdom of Local Wisdom of Limas Palembang Traditional House as Malay Community Criteria'. Vol. 5, No. 1, Tahun 2018. ISSN 2355-2484 (print) - ISSN 2550-1194 (online). http://jurnal.untan.ac.id/index.php/lb/article/view/25383

[16] Effendy, T. (2006). Teach Malay Teachers. Malay Culture Study and Development Center. Yogyakarta.

[17] Kaelan, (2008).Pancasila Education Paradigm Publisher. Yogyakarta.

[18] Fajar, I. W \& Zain, Z. (2014). 'Design the structure in the Local Wisdom Perpective (Loka Wisdom Perpsective) on Traditional Malay Houses in Sambas City, West Kalimantan. Vol 1, No 2 (2014). ISSN 2355-2484 (Print) - ISSN 2550-1194 (Online) http://jurnal.untan.ac.id/index.php/Ib/article/view/1897

[19] Anisa, \& Halimah, L. (2018). 'Internalization of the Value of Citizenship Education in the Blakanan Sea Party Tradition in the Ideal Development Framework for Democtaric Residents. Vol.15 No. 2, hh. 148-160. Year 2018 1480160. ISSN 1829-5789 (Print) - ISSN 2541-1918 (Online). https://journal.uny.ac.id/index.php/civics./index.

[20] Insrawardana, I. (2012). 'Traditional Wisdom of the Sundanese Society in Relation to the Natural Environment. Vol. 4, No. 1. https://journal.unnes.ac.id/nju/index.php/kominitas/article/view/2390

[21] Sukmayadi, T. (2018). Kajian tentang karakter berbasis nilai-nilai kearifan lokal pada masyarakat adat Kampung Kuta Kecamatan Tambaksari Kabupaten Ciamis. Vol. 13, No. 1 (2016). p-issn: 1829-5789 e-issn: 2541-1918.

https://journal.uny.ac.id/index.php/civics./index

[22] Priyatna, M. (2017).'Local Wisdom Based Character Education' Journal of Islamic Education Journal of Islamic Education. Vol. 05. No. 10, hh. 11-24. P-ISSN: 2614-4018, EISSN: 2614-8846. http://jurnal.staialhidayahbogor.ac.id/index.php.ei/article/view/6 . 